\title{
Present state of common vector-borne diseases in Canada
}

\author{
Lindsay $\mathrm{LR}^{1 *}$
}

\author{
Affiliation \\ ${ }^{1}$ National Microbiology Laboratory, Public Health Agency of Canada, Winnipeg, MB \\ *Correspondence: robbin.lindsay@phac-aspc.gc.ca
}

Suggested citation: Lindsay LR. Present state of common vector-borne diseases in Canada. Can Comm Dis Rep 2016;42:200-1. https://doi.org/10.14745/ccdr.v42i10a03

\section{Background}

With a few exceptions, for example, malaria in southern Ontario in the 1800s, vector-borne diseases in Canada have been relatively rare. However, in recent years, both West Nile virus and Lyme disease have emerged as significant public health concerns in many parts of Canada.

\section{Objective}

To summarize the factors that are driving the emergence of West Nile virus and Lyme disease and describe the surveillance methodologies currently used to assess the overall risk of human exposure.

\section{Narrative}

The main drivers that have been facilitating the emergence of vector-borne diseases in Canada are increasing rainfall, rising temperatures and increased host availability. To date, Canada has been fortunate in not having local mosquito-borne transmission of Zika virus, chikungunya or dengue as the climate is too cool for the main mosquito vectors, Aedes aegypti and Aedes albopictus, to survive.

West Nile virus, transmitted primarily by culex mosquitoes (1), is the most common mosquito-borne illness in Canada. Birds are amplifying hosts, increasing the presence and distribution of West Nile virus in the environment. Historically, surveillance relied on the collection and testing of dead birds; currently, the primary surveillance mechanism involves collecting and testing mosquitoes. Mosquito surveillance is relatively expensive and has been prone to cutbacks when the annual number of West Nile virus cases is low. However, under appropriate environmental conditions, large outbreaks of West Nile have occurred after many years of limited virus activity. As a result, maintaining adequate surveillance capacity to define the risk from West Nile virus has been a significant challenge in many Canadian jurisdictions.

Lyme disease is the most common tick-borne illness in Canada, and the vectors are the blacklegged ticks (Ixodes scapularis) found in southern parts of Manitoba, Ontario, Quebec,
Nova Scotia and New Brunswick and Ixodes pacificus in British Columbia $(2,3)$. Surveillance to better define the risk of human exposure to infected ticks relies upon assessment of environmental risk (i.e. defining where blacklegged tick populations predominate). The rate of range expansion of blacklegged tick populations in eastern and central Canada has been so dramatic in the last 15 years that the relatively simple method of "drag sampling" (passing a cloth over the ground in a systematic manner to sample for host-seeking ticks) has replaced the more labour-intense method of collecting and testing small mammal hosts. In addition, Lyme disease was made nationally notifiable in 2009 so that the epidemiology of the disease could be more clearly defined and examined over time.

The number of Lyme disease cases reported has increased exponentially in the last five years; a number of urban areas are now affected. One of the biggest challenges is making health professionals aware of the ever-expanding areas with infected blacklegged ticks and ensuring that patients are promptly diagnosed and appropriately treated. Unlike West Nile virus, diagnostic testing for Lyme disease lacks sensitivity in the early stages of the disease; however, work is underway to improve the accuracy of diagnostic tests (4).

The epidemiology of West Nile virus and Lyme disease in Canada are markedly different. West Nile virus demonstrates patterns of "boom and bust," with outbreaks often followed by many years of few human infections. Lyme disease cases are much more consistent and are increasing each year, driven in part by the range expansion of the tick vectors.

\section{Conclusion}

Both West Nile virus and Lyme disease are known to affect populations in urban settings. Maintaining effective surveillance programs is key to understanding the dynamics of human risk and measuring the effectiveness of disease prevention strategies to minimize the impact of these pathogens on the health of Canadians.

\section{Conflict of interest}

None. 


\section{References}

1. Zheng H, Drebot MA, Coulthart MB. West Nile virus in Canada: ever-changing, but here to stay. Can Comm Dis Rep 2014;40-10:173-7. http://www.phac-aspc.gc.ca/ publicat/ccdr-rmtc/14vol40/dr-rm40-10/dr-rm40-10-commeng.php.

2. Ogden NH, Koffi JK, Pelcat Y, Lindsay LR. Environmental risk from Lyme disease in central and eastern Canada: a summary of recent surveillance information. Can Comm Dis Rep 2014;40-5:74-82. http://www.phac-aspc.gc.ca/publicat/ ccdr-rmtc/14vol40/dr-rm40-05/dr-rm40-05-1-eng.php
3. Hatchette TF, Johnston BL, Schleihauf E, Mask A, Haldane D, Drebot M, Baikie M, Cole TJ, Fleming S, Gould R, Lindsay R. Epidemiology of Lyme disease, Nova Scotia, Canada, 20022013. Emerg Infect Dis. 2015;21(10):1751-8.

4. Lindsay LR, Bernat K, Dibernardo A. Laboratory diagnostics for Lyme disease. Can Comm Dis Rep 2014;40:209-14. http://www.phac-aspc.gc.ca/publicat/ccdr-rmtc/14vol40/drrm40-11/dr-rm40-11-lyme-2-eng.php.
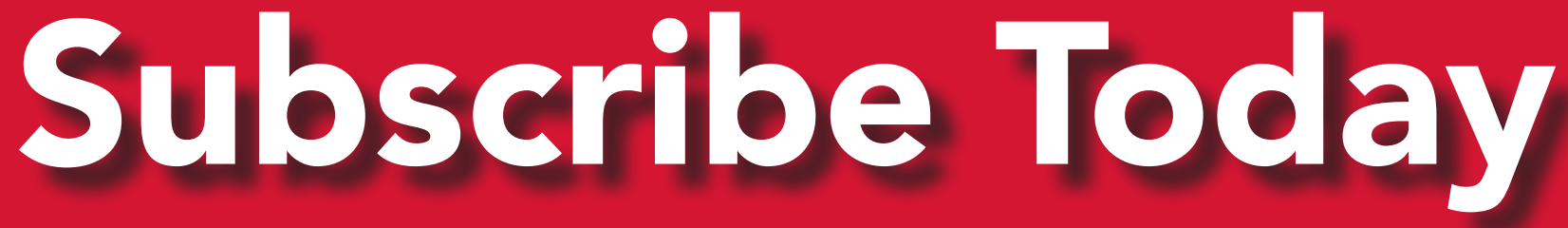

\section{new issues straight to your inbox.}

Subscribe to CCDR online and receive
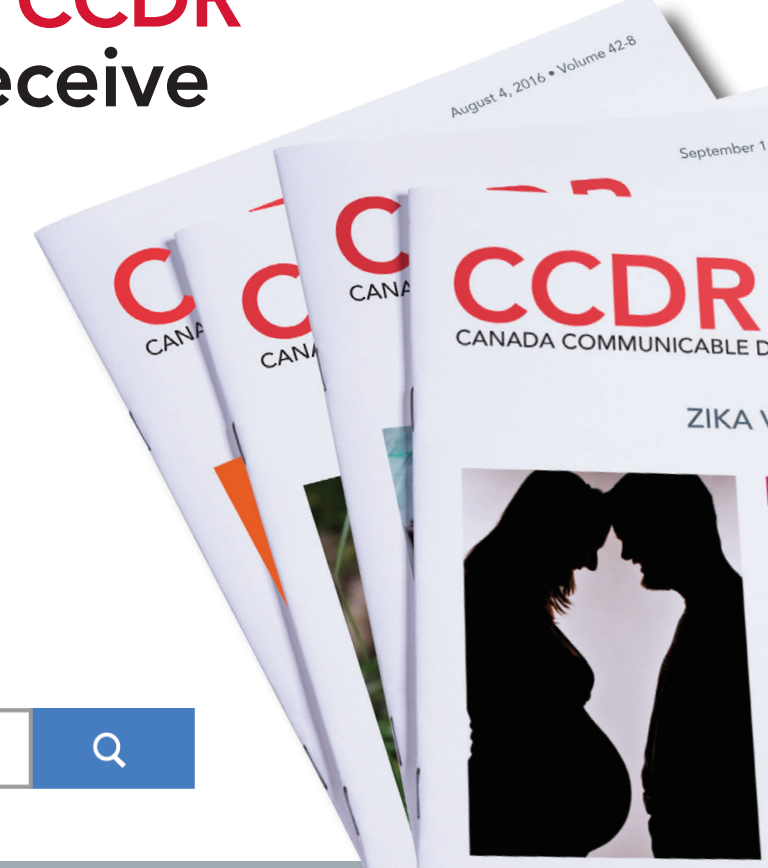

Recommendat recommendations on Zika,
sexual transmission and pregnant women

Web Search CCDR+Subscribe 